\title{
Hasil Belajar IPA Siswa SD di Daerah Tertinggal dengan Penerapan Model Pembelajaran Inkuiri Terbimbing
}

\author{
Ricardus Jundu, Pius Herman Tuwa, Rosnadiana Seliman \\ rickyjundu@gmail.com \\ Universitas Katolik Indonesia Santu Paulus Ruteng
}

\begin{abstract}
The Influence to Science Learning Results for Elementary School Students in Underdeveloped Regions with The Implementation of Guided Inquiry Model
\end{abstract}

\begin{abstract}
This study aims to determine the effect of the use of guided inquiry methods on students' science learning results at SDI Wae Ratun. This school is one of the schools in underdeveloped regions. This type of research is a quasi-experimental study with posttest only control group design research. The subject of the study was the fifth-grade students with sampling techniques using random class techniques. The sample chosen in this study was class $V B$ as the experimental class and class $V A$ as the control class. The instrument used is a test in the form of multiple-choice questions. Data analysis uses descriptive and inferential statistics. The results of data analysis obtained the calculation of $t_{\text {count }}=4.940$ and $t_{\text {table }}=2.026$ at a significant level and degrees of freedom $=35$. Thus, there is a substantial influence on the use of guided inquiry learning models on student science learning results at SDI Wae Ratun.
\end{abstract}

Keywords: Guided Inquiry Model, Learning Results of Science, Underdeveloped Region

Received date: 8 September 2019

Article Info

Revised date: 1 April 2020

Accepted date: 12 Mei 2020

\section{PENDAHULUAN}

Pendidikan berdasarkan UUD 45 merupakan hak setiap orang sehingga kelayakan pendidikan perlu menjadi pertimbangan dalam proses pelaksanaannya. Kesalahan dalam proses pendidikan akan berdampak pada keterbelakangan sumber daya manusia. Kebutuhan di era industri 4.0 tidak terlepas dari sumber daya yang berkualitas. Apakah pendidikan yang berkualitas sudah tercapai? Tentunya, masih banyak daerah yang belum menikmati pendidikan yang layak di Indonesia. Berbagai wilayah di Indonesia masih banyak yang masuk kategori daerah tertinggal. Ketertinggalan suatu daerah bukan berarti pendidikannya juga ikutan tertinggal. Lembaga pendidikan harus menyadari bahwa untuk keluar dari ketertinggalan itu maka perlu usaha untuk meningkatkan kualitas pendidikan.

Guru harus mempersiapkan siswanya untuk beradaptasi dengan berbagai perkembangan di era revolusi industri 4.0. Perkembangan teknologi berkaitan erat dengan perkembangan sains sehingga sangat penting untuk dipelajari siswa sejak dini di sekolah dasar (Santiasih, 2013). Dengan demikian, pembelajaran Ilmu Pengetahuan Alam (IPA) dapat memberikan pengalaman secara langsung melalui berbagai keterampilan dan sikap ilmiah yang menunjang peningkatan hasil belajar siswa.

Belajar IPA difokuskan pada pengalaman siswa dalam belajar dengan menerapkan sistem belajar mandiri yaitu mencari jawaban atas permasalahan sendiri untuk menambah pemahaman konsep (Mertiana, 2011). Guru harus menyadari bahwa pengalaman belajar siswa menjadi hal penting dalam pembelajaran. Realita menunjukkan guru lebih mendominasi proses pembelajaran dengan menerapkan metode ceramah sehingga pembelajaran terkesan monoton dan membosankan (Lestari, 2013). Belajar IPA sangat sulit menerapkan metode ceramah karena berkaitan dengan keterampilan berpikir, bekerja, sikap ilmiah, dan komunikasi (Wulandari, 2012). Belajar IPA membutuhkan model pembelajaran yang tepat untuk diterapkan dalam pembelajaran. Salah satunya yaitu model pembelajaran inkuiri. Pembelajaran inkuiri akan memberikan sumbangan berarti bagi keterampilan siswa dalam berpikir, bekerja, dan berkomunikasi serta meningkatkan sikap ilmiah.

Pembelajaran di kelas membutuhkan perlakuan yang bervariasi dalam menjamin kualitas proses belajar siswa. Model pembelajaran inkuiri akan memberikan pengalaman belajar yang baru bagi siswa dengan bimbingan dan tuntunan guru menggunakan prosedur yang tepat untuk meningkatkan kualitas 
belajar siswa. Dalam belajar siswa tidak bisa mandiri tanpa bimbingan dan arahan guru untuk menuntun siswa menuju proses belajar yang ideal. Oleh karena itu, model pembelajaran inkuiri yang tepat berdasarkan hal tersebut yaitu model pembelajaran inkuiri terbimbing.

Belajar IPA membutuhkan proses inkuiri dengan alasan yaitu dapat memberi pengalaman baru bagi siswa sehingga proses belajar menjadi aktif dan berpusat pada siswa (Damayati, 2014; Wahyuni, 2016). Model pembelajaran inkuiri terbimbing berpengaruh pada hasil belajar siswa karena memberikan pengalaman baru dalam proses belajar. Hal ini sesuai dengan hasil penelitian Sumarni, Santoso, \& Suparman (2017) yaitu model pembelajaran inkuiri terbimbing berpengaruh pada hasil belajar kognitif siswa. Penelitian Udiani, Marhaeni, \& Arnyana (2017) juga menginformasikan bahwa model pembelajaran inkuiri terbimbing memiliki pengaruh terhadap hasil belajar IPA siswa. Pembelajaran IPA sangat terbantu ketika guru bisa menggunakan model pembelajaran inkuiri terbimbing dengan tepat. Sekolah di daerah terpencil ketika menerapkan model pembelajaran yang sesuai dengan karakteristik materi pelajaran maka akan sangat membantu memaksimalkan proses pembelajaran dalam keterbatasan daerah tertinggalnya.

SDI Wae Ratun merupakan salah satu sekolah dasar (SD) yang wilayahnya masuk kategori daerah tertinggal. Banyak kekurangan di daerah tertinggal seperti fasilitas penunjang dan akses informasi sehingga menyebabkan daerah tertinggal jauh tertinggal dari daerah perkotaan. Fasilitas dan akses informasi di sekolah sangat diperlukan untuk peningkatan mutu dan kualitas pembelajaran di kelas. Kekurangan fasilitas dan akses informasi menyebabkan proses pembelajaran cenderung berorientasi pada guru. Pembelajaran konvensional kurang melibatkan peran siswa dalam kegiatan pembelajaran sehingga mengurangi minat siswa untuk serius selama proses pembelajaran berlangsung (Amijaya, Ramdani, \& Merta, 2018). Oleh karena itu, guru membutuhkan desain pembelajaran yang tepat dengan melakukan inovasi untuk menerapkan secara baik model pembelajaran.

Berdasarkan berbagai uraian di atas maka model pembelajaran inkuiri terbimbing dapat menjadi rekomendasi bagi guru di daerah tertinggal untuk membantu proses belajar IPA bagi siswa. Model pembelajaran inkuiri hanya membutuhkan keterampilan guru dalam mendesain dan menerapkannya bukan fasilitas yang canggih. Daerah tertinggal bukan alasan untuk tidak memperhatikan kualitas dari proses pembelajaran di kelas karena guru bisa menggunakan dan memanfaatkan berbagai cara yang sesuai untuk memajukan pendidikan. Jika fasilitas kurang memadai maka guru bisa menggunakan pembelajaran yang kontekstual.

\section{KAJIAN PUSTAKA}

\section{Model Pembelajaran Inkuiri Terbimbing}

Model pembelajaran inkuiri merupakan rangkaian kegiatan belajar yang fokus pada pengalaman dan keterlibatan aktif siswa dengan melibatkan seluruh kemampuannya untuk belajar secara sistematis, kritis, logis, dan analitis berkaitan dengan berbagai konsep dan prinsip (Damayati, 2014). Aktivitas siswa menjadi pengalaman baru dalam hidupnya sehingga proses belajar dengan rancangan model inkuiri mendukung peningkatan berbagai aspek kemampuan siswa. Model pembelajaran inkuiri lebih fokus menyediakan bimbingan dan petunujk kepada siswa. Kegiatan siswa lebih terarah pada aktivitas penyelidikan berdasarkan masalah yang ada untuk menentukan prosedur penyelidikan.

Pembelajaran yang sifatnya kontekstual berhubungan dengan desain model pembelajaran inkuiri terbimbing. Model pembelajaran inkuiri terbimbing merupakan kegiatan belajar yang melibatkan kemampuan siswa berdasarkan proses berpikir secara kritis dan analitis menyelesaikan permasalahan yang ada melalui observasi dan eksperimen (Wulanningsih, 2012). Model pembelajaran inkuiri terbimbing menjadi model pembelajaran yang efektif dalam meningkatkan aktivitas siswa dalam proses pembelajaran (Iswatun, Mosik, \& Subali, 2017). Siswa lebih aktif dan guru hanya memberikan bimbingan dan petunjuk teknis pelaksanaan prosedur penyelidikan masalah.

Dalam melakukan penyelidikan siswa harus terbiasa untuk melakukan proses pemecahan masalah (Jundu, Prodjosantoso, Ramda \& Jelatu, 2018). Peran guru bertujuan agar proses penyelidikan berjalan sistematis, teratur, logis, kritis, dan analitis sesuai desain pembelajaran yang sudah direncanakan. Dengan demikian, proses pembelajaran dengan melibatkan aktivitas siswa cenderung mengurangi proses hafalan dan siswa diarahkan untuk meningkatkan pemahaman konsep (Zani, Adlim, $\&$ Safitri, 2018). 
Langkah-langkah dalam penerapan model pembelajaran inkuiri terbimbing yaitu Introduction; Questioning; Planning; Implementing; Concluding; Reporting (Kuhlthau, dkk, 2007). Langkah pembelajarannya dapat dilihat pada Tabel 1 berikut.

Tabel 1. Langkah Pembelajaran Inkuiri Terbimbing

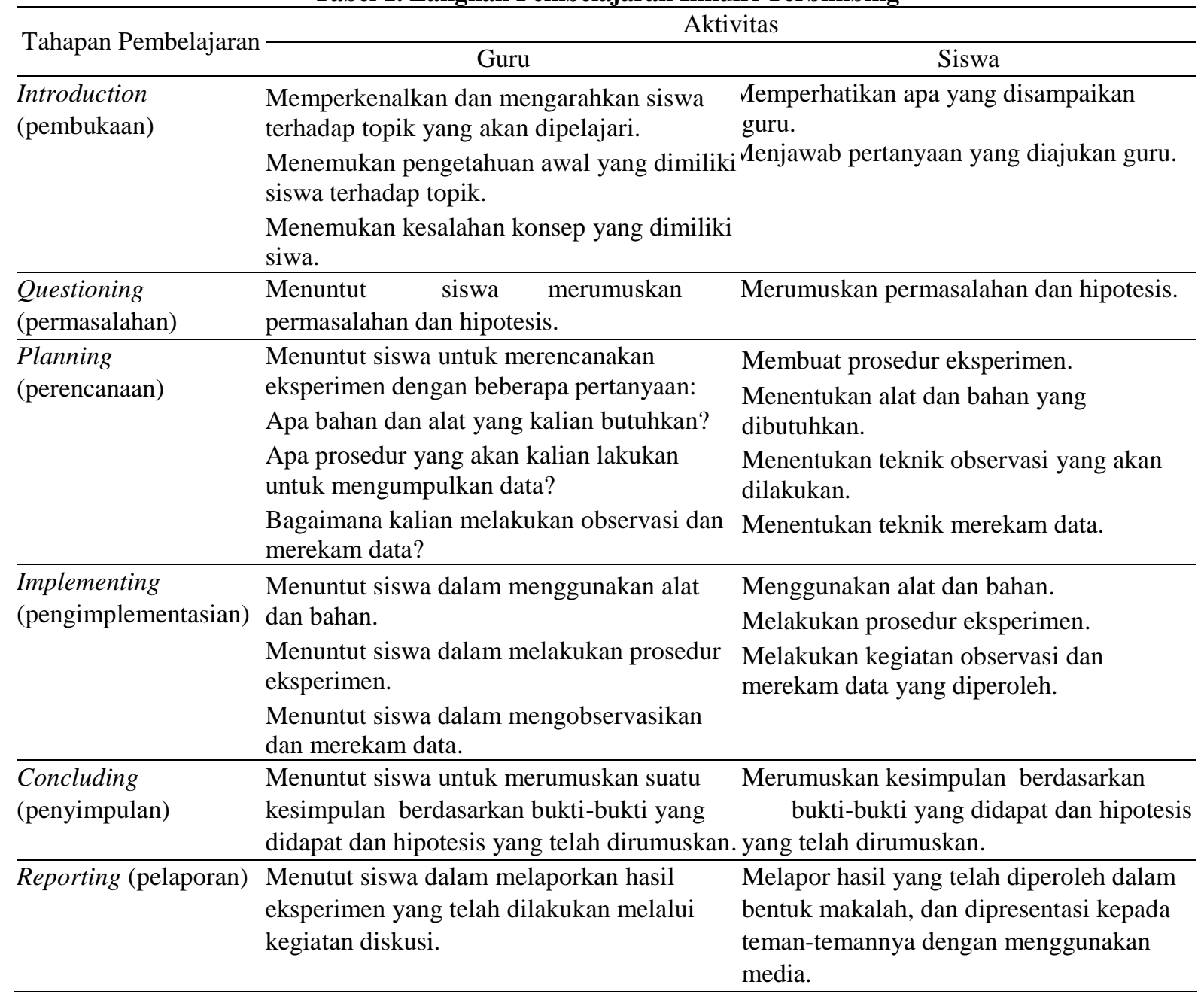

Kelebihan model pembelajaran inkuiri terbimbing (Roestiyah, 2012:76-77).

1. Membentuk dan mengembangkan "sel-concept" pada diri siswa;

2. Membantu dalam menggunakan ingatan dan transfer pada situasi proses belajar yang baru;

3. Mendorong siswa untuk berpikir dan bekerja keras atas inisiatifnya sendiri, bersikap obyektif, jujur, dan terbuka;

4. Mendorong siswa untuk berpikir dalam merumuskan hipotesisnya sendiri.

\section{Hasil belajar IPA SD}

Belajar merupakan suatu proses perubahan yang berkaitan dengan perubahan tingkah laku sebagai hasil dari interaksi dengan lingkungannya dalam memenuhi kebutuhan hidupnya (Slameto, 2010:2). Perubahan yang terjadi berhubungan dengan berbagai aspek tingkah laku yang secara nyata mempengaruhi kehidupan seseorang. Perubahan yang terjadi sebagai usaha untuk memperoleh pengalaman dan cara berinteraksi dengan lingkungan.

Hasil belajar erat kaitannya dengan pencapaian dalam memperoleh kemampuan sesuai dengan tujuan yang direncanakan. Dengan demikian, tugas utama guru dalam kegiatan ini yaitu merancang instrumen yang dapat mengumpulkan data tentang keberhasilan siswa dalam mencapai tujuan pembelajaran.

Faktor-faktor yang mempengaruhi belajar siswa dapat dibedakan menjadi tiga macam (Syarifuddin, 2011), yaitu sebagai berikut. 
Hasil Belajar IPA Siswa SD di Daerah Tertinggal dengan Penerapan Model Pembelajaran Inkuiri

Terbimbing (Ricardus Jundu, Pius Herman Tuwa, Rosnadiana Seliman)

1. Faktor internal (faktor dari dalam siswa), yakni kondisi jasmani dan rohani siswa.

2. Faktor eksternal (faktor dari luar siswa), yakni kondisi lingkungan di sekitar siswa.

3. Faktor pendekatan belajar (approach to learning), yakni jenis upaya belajar siswa yang meliputi strategi dan metode yang digunakan siswa untuk melakukan kegiatan pembelajaran materi-materi pelajaran.

Pembelajaran IPA merupakan salah satu mata pelajaran yang terdapat dalam K13 untuk tingkat SD. IPA menjadi Pengetahuan sistematis yang tersusun secara teratur, rasional, dan objektif berupa kumpulan data hasil observasi dan eksperimen (Samatowa, 2011). Hal ini berarti bahwa, pembelajaran IPA di SD menekankan pada pemberian pengalaman belajar secara langsung melalui pengembangan keterampilan proses dan sikap ilmiah. Pembelajaran IPA diarahkan untuk mencari tahu sendiri jawaban atas pertanyaan atau masalah sehingga dapat membantu siswa untuk memperoleh pemahaman yang lebih mendalam tentang alam sekitar seperti makhluk hidup, benda atau materi, serta energi dan perubahannya (Mertiana, 2011).

Hasil belajar IPA berhubungan dengan pencapaian kemampuan siswa dalam menguasai pengetahuan yang sistematis, teratur, rasional, dan objektif dari hasil observasi dan eksperimen tentang makhluk hidup, benda atau materi, serta energi dan perubahannya. Hasil belajar IPA siswa yang baik dapat dicapai apabila siswa melalui proses pembelajaran yang tepat dengan penekanan pada keterampilan proses. Selain itu, keberhasilan belajar IPA siswa tergantung dari perlakuan yang diberikan guru pada siswa dalam proses pembelajaran (Widiantono \& Hajono, 2017). Keterampilan proses berhubungan dengan tingkah laku siswa sebagai hasil adanya pemberian perlakuan dari guru untuk menemukan masalah, membuat hipotesis, menganalisis, dan menarik kesimpulan yang diperoleh.

Penelitian Udiani, Marhaeni, \& Arnyana (2017) menginformasikan bahwa model pembelajaran inkuiri terbimbing memiliki pengaruh terhadap hasil belajar IPA siswa. Model pembelajaran inkuiri terbimbing membantu siswa untuk meningkatkan hasil belajar IPA karena pada proses pembelajaran siswa lebih aktif untuk mencari informasi dan menganalisis suatu masalah. Proses belajar siswa tidak mengarah ke hafalan tetapi mengerjakan sehingga membantu proses mengingat siswa. Hasil penelitian Sumarni, Santoso, \& Suparman (2017) juga menegaskan bahwa model pembelajaran inkuiri terbimbing berpengaruh pada hasil belajar kognitif siswa. Selain itu, hasil penelitian Pratiwi, Wijayati, Mahatmanti, \& Marsudi (2019) menunjukkan hasil bahwa pembelajaran menggunakan model pembelajaran inkuiri terbimbing berbasis penilaian autentik berpengaruh pada hasil belajar siswa. Hasil belajar yang baik tentunya ditunjang dengan desain proses pembelajaran yang sesuai. Dengan demikian, model pembelajaran inkuiri terbimbing bisa menjadi acuan dalam mengoptimalkan hasil belajar IPA siswa.

\section{Hipotesis Penelitian}

Hipotesis dalam penelitian ini yaitu ada pengaruh yang signifikan penggunaan model pembelajaran inkuiri terbimbing terhadap hasil belajar IPA siswa di SDI Wae Ratun.

\section{METODE PENELITIAN}

Jenis Penelitian ini merupakan penelitian kuasi eksperimen dengan maksud untuk mengetahui pengaruh suatu perlakuan terhadap subyek penelitian. Perlakuan yang diberikan yaitu penggunaan model pembelajaran inkuiri untuk mengetahui pengaruhnya terhadap hasil belajar IPA siswa SD. Desain penelitian yang digunakan yaitu posttest only control group design. Penelitian ini menggunakan dua kelas sebagai subyek penelitian yaitu kelas eksperimen dan kelas kontrol. Kelas eksperimen diberikan perlakuan menggunakan model pembelajaran inkuiri terbimbing dan kelas kontrol menggunakan model pembelajaran yang konvensional. Desain penelitiannya disajikan pada Tabel 2 berikut.

Tabel 2. Desain Penelitian

\begin{tabular}{cccc}
\hline No & Kelas & Perlakuan & Posttest \\
\hline 1 & Eksperimen & $\mathrm{X}_{1}$ & $\mathrm{O}_{1}$ \\
\hline 2 & Kontrol & $\mathrm{X}_{2}$ & $\mathrm{O}_{1}$ \\
\hline
\end{tabular}

Keterangan:

$\mathrm{X}_{1}$ : Model pembelajaran inkuiri

$\mathrm{X}_{2}$ : Model pembelajaran yang konvensional

$\mathrm{O}_{1}$ : Posttest 
Populasi dalam penelitian ini yaitu hasil belajar siswa kelas V di SDI Wae Ratun. Sampel dipilih dengan teknik cluster random sampling menggunakan randomisasi kelompok (Dantes, 2012: 44). Kelas yang terpilih sebagai kelas eksperimen yaitu kelas VB dan kelas kontrol yaitu VA. Variabel yang digunakan yaitu model pembelajaran inkuiri terbimbing dan hasil belajar IPA siswa pada materi gaya, gerak, dan energi serta fungsinya. Teknik pengumpulan data yang digunakan dalam penelitian ini adalah test dalam bentuk pilihan ganda. Data penelitian yang digunakan berasal dari hasil belajar IPA siswa.

Penelitian ini menggunakan teknik analisis deskriptif dan inferensial. Analisis deskriptif untuk mengkaji data secara deskriptif dan teknik inferensial untuk menguji hipotesis penelitiannya. Sebelum melakukan uji hipotesis terlebih dahulu dilakukan uji prasyarat seperti uji normalitas dan homogenitas data. Uji normalitas data dalam penelitian ini menggunakan rumus Chi-kuadrat $\left(\chi^{2}\right)$. Uji homogenitas data dalam penelitian ini yaitu menggunakan uji $\mathrm{F}$. Uji hipotesis menggunakan uji t dengan rumus separated varian.

\section{HASIL PENELITIAN DAN PEMBAHASAN}

\section{Hasil Penelitian}

Hasil penelitian pertama berupa data statistik deskriptif. Hasil deskriptif hasil belajar IPA siswa disajikan pada Tabel 3 sebagai berikut.

Tabel 3. Hasil Analisis Deskriptif Hasil Belajar IPA Siswa Kelas Eksperimen dan Kontrol

\begin{tabular}{lcc}
\hline Data Statistik Deskriptif & Eksperimen & Kontrol \\
\hline Mean & 79,00 & 69,21 \\
\hline Nilai Max & 95,00 & 90,00 \\
\hline Nilai Min & 65,00 & 55,00 \\
\hline Varians $\left(\mathrm{s}^{2}\right)$ & 87,00 & 67,40 \\
\hline Standar deviasi (SD) & 9,00 & 8,21 \\
\hline
\end{tabular}

Tabel 3 menginformasikan bahwa nilai rata-rata kelas eksperimen yaitu 79 dan kelas kontrol 69,21 serta nilai maksimum dan minimum kelas eksperimen lebih tinggi dibandingkan kelas kontrol yang berarti bahwa kelas eksperimen yang menggunakan model pembelajaran inkuiri terbimbing lebih baik dari kelas kontrol yang menerapkan pembelajaran konvensional.

Hasil penelitian kedua berupa hasil uji prasyarat sebelum dilakukan uji hipotesis yaitu uji normalitas dan homogenitas data. Hasilnya disajikan pada Tabel 4 dan Tabel 5 sebagai berikut.

Tabel 4. Hasil Uji Normalitas Data

\begin{tabular}{llll}
\hline Kelas & $\mathrm{N}$ & $\chi^{2}$ Hitung & $\chi^{2}$ Tabel \\
\hline Eksperimen & 18 & 7,4 & 9,48773 \\
\hline Kontrol & 19 & 2,3 & 9,48773 \\
\hline
\end{tabular}

Tabel 4 menunjukkan bahwa data hasil belajar IPA siswa berdistribusi normal karena $\chi^{2}$ Hitung kelas eksperimen 7,4 dan kelas kontrol 2,3 kurang dari $\chi^{2}$ Tabel. Dengan demikian, dapat dilakukan uji prasyarat berikutnya yaitu uji homogenitas.

Tabel 5. Hasil Uji Homogenitas Data

\begin{tabular}{lcc}
\hline Kelas & $f_{\text {hitung }}$ & $f_{\text {tabel }}$ \\
\cline { 1 - 1 } Eksperimen & 1,1 & 2,23 \\
\hline Kontrol & 1,1 & \\
\hline
\end{tabular}

Tabel 5 menunjukkan bahwa data hasil belajar IPA siswa homogen karena $f_{\text {hitung }}$ yaitu 1,1 kurang dari $f_{\text {tabel }}$ yaitu 2,23. Dengan demikian, setelah data diketahui berdistribusi normal dan homogen maka selanjutnya dilakukan uji hipotesis menggunakan uji t. berikut.

Hasil penelitian ketiga yaitu hasil uji hipotesis. Uji hipotesis disajikan pada Tabel 6 sebagai 
Hasil Belajar IPA Siswa SD di Daerah Tertinggal dengan Penerapan Model Pembelajaran Inkuiri

Terbimbing (Ricardus Jundu, Pius Herman Tuwa, Rosnadiana Seliman)

Tabel 6. Hasil Uji Hipotesis

\begin{tabular}{|c|c|c|c|}
\hline Kelas & $\mathrm{t}_{\text {hitung }}$ & $\mathrm{t}_{\text {tabel }}(\alpha=0,05$ & Kesimpulan \\
\hline $\begin{array}{l}\text { Eksperimen } \\
\text { Kontrol }\end{array}$ & 4,940 & 2,026 & $\mathrm{H}_{0}$ ditolak dan $\mathrm{H}_{1}$ diterima \\
\hline
\end{tabular}

Tabel 6 menunjukkan bahwa $\mathrm{H}_{0}$ ditolak dan $\mathrm{H}_{1}$ diterima dengan $\mathrm{t}_{\text {hitung }} 4,940>\mathrm{t}_{\text {tabel }} 2,026$. Hasil uji hipotesis menunjukkan bahwa ada pengaruh yang signifikan penggunaan model pembelajaran inkuiri terbimbing terhadap hasil belajar IPA siswa. Dengan demikian, ada pengaruh pemberian perlakuan pada sampel yang mempengaruhi hasil belajar siswa.

\section{Pembahasan}

Berdasarkan Tabel 3, nilai rata-rata kelas eksperimen lebih tinggi dari pada mean kelas kontrol yaitu $79>69,21$, dengan selisih nilai mean hasil belajar IPA siswa kelas eksperimen dan kelas kontrol adalah 9,79. Berdasarkan uji statistik deskriptif menginformasikan bahwa hasil belajar IPA siswa yang diajarkan dengan menggunakan model pembelajaran inkuiri terbimbing lebih tinggi dari hasil belajar IPA siswa yang diajarkan dengan menggunakan model pembelajaran yang konvensional. Hal ini sesuai dengan pendapat Roestiyah (2012:76-77) bahwa pemberian perlakuan dengan model pembelajaran inkuiri terbimbing memiliki kelebihan karena menekankan pada sel-concept pada diri siswa, mendorong siswa untuk berpikir dan bekerja keras atas inisiatifnya sendiri, dan mendorong siswa untuk berpikir dalam merumuskan hipotesisnya sendiri. Pembelajaran konvensional cenderung lebih membuat siswa jenuh sesuai hasil penelitian Amijaya, Ramdani, \& Merta (2018) karena aktivitas pembelajaran jarang melibatkan siswa.

Dengan demikian, secara deskriptif hasil penelitian memberikan informasi bahwa model pembelajaran inkuiri terbimbing dapat meningkatkan hasil belajar IPA siswa. Peningkatan hasil belajar IPA siswa ditunjang dari proses penerapan model pembelajaran inkuiri terbimbing secara tepat. Data nilai maksimum dan minimumnya mendukung kesimpulan bahwa kelas eksperimen lebih tinggi dari kelas kontrol sehingga penerapan model pembelajaran inkuiri terbimbing dapat menjadi faktor peningkatan hasil belajar IPA siswa.

\section{Pengaruh Model Pembelajaran Inkuiri Terbimbing Terhadap Hasil Belajar IPA Siswa}

Secara inferensial dari hasil uji hipotesis penelitian diperoleh hasil $t_{\text {hitung }}=4,940>t_{\text {tabel }}=2,026$ sehingga $\mathrm{H}_{0}$ ditolak dan $\mathrm{H}_{1}$ diterima sehingga terdapat pengaruh yang signifikan penggunaan model pembelajaran inkuiri terbimbing terhadap hasil belajar IPA siswa. Hasil penelitian ini sesuai dengan hasil penelitian sebelumnya yang telah dilakukan Udiani, Marhaeni, \& Arnyana (2017) menginformasikan bahwa model pembelajaran inkuiri terbimbing memiliki pengaruh terhadap hasil belajar IPA siswa. Model pembelajaran inkuiri terbimbing membantu siswa untuk meningkatkan hasil belajar IPA karena pada proses pembelajaran siswa lebih aktif untuk mencari informasi, menganalisis suatu masalah, dan menarik sendiri kesimpulan. Proses belajar siswa tidak menghafal tetapi mengerjakan sehingga membantu proses mengingat siswa. Hasil ini juga didukung oleh data deskriptif yang memberikan gambaran bahwa model pembelajaran inkuiri terbimbing ini dapat meningkatkan hasil belajar IPA siswa.

Pada pembelajaran konvensional lebih menekankan pada dominasi guru dalam proses pembelajaran. Siswa menjadi pasif dan hanya mengandalkan guru dalam belajar sehingga siswa pada akhirnya sampai pada titik jenuh yang berdampak pada berkurangnya motivasi untuk belajar.

Belajar menggunakan model pembelajaran inkuiri terbimbing dapat mengacu pada keinginan siswa untuk mengembangkan ide dan gagasannya melalui percobaan-percobaan ilmiah secara kelompok dan memiliki keterampilan berpikir kritis. Syarifuddin (2011) menjelaskan bahwa salah satu faktor penentu keberhasilan belajar siswa yaitu faktor pendekatan belajar yang diterapkan pada siswa. Penerapan model pembelajaran inkuiri terbimbing berorientasi tidak hanya pada hasil belajar tetapi juga berorientasi pada proses pembelajarannya. Dalam penerapannya, pembelajaran lebih berpusat pada siswa dan siswa pun belajar tidak berdasarkan hafalan tetapi berdasarkan pengalaman sehingga pemahaman siswa bertambah.

Model pembelajaran inkuiri terbimbing merupakan model pembelajaran yang inovatif bagi guru dan siswa dalam mempelajari IPA. Alasannya, desain pembelajaran ini memotivasi siswa untuk aktif dalam belajar dengan memanfaatkan pendekatan kontekstual. Selain itu, Pembelajaran IPA 
diarahkan untuk mencari tahu sendiri jawaban atas pertanyaan atau masalah sehingga dapat membantu siswa untuk memperoleh pemahaman yang lebih mendalam tentang alam sekitar seperti makhluk hidup, benda atau materi, serta energi dan perubahannya (Mertiana, 2011).

Motivasi guru berdampak pada perubahan paradigma belajar dari berpusat pada guru menjadi berpusat pada siswa. Belajar aktif melibatkan secara maksimal seluruh kemampuan siswa dalam menyelidiki masalah sehingga siswa dapat merumuskan sendiri pengetahuan dari masalah yang telah dipecahkan. Pembelajaran IPA di SD menekankan pada pemberian pengalaman belajar secara langsung melalui pengembangan keterampilan proses dan sikap ilmiah (Samatowa, 2011). Dengan demikian, meningkatkan kualitas belajar siswa tidak hanya terletak pada fasilitas yang memadai saja melainkan juga dengan merubah paradigma lama guru untuk berinovasi dan kreatif dalam memembimbing belajar siswa. Guru harus mampu berinovasi dan kreatif dalam mendesain pembelajaran sehingga tujuan pembelajaran bisa tercapai.

Pembelajaran yang didesain dengan baik bisa memeberikan efek baru bagi pengalaman belajar siswa dan berlanjut pada peningkatan hasil belajar IPA siswa. Desain pembelajaran menggunakan model pembelajaran inkuiri terbimbing menunjukkan hasil adanya pengaruh terhadap hasil belajar IPA siswa. Hasil statistik deskriptif dan inferensial yang menunjukkan bahwa penerapan model pembelajaran inkuiri terbimbing berpengaruh secara signifikan terhadap hasil belajar IPA siswa dan mampu meningkatkan hasil belajarnya. Kelebihan model pembelajaran inkuiri terbimbing yaitu bisa memanfaatkan persoalan yang sifatnya kontekstual dengan kehidupan siswa sehingga permasalahan yang diangkat berkaitan dengan kehidupan siswa.

\section{Penerapan Model Pembelajaran Inkuiri Terbimbing di Daerah Tertinggal}

Model pembelajaran inkuiri terbimbing sangat membantu guru di daerah tertinggal untuk meningkatkan hasil belajar siswa. Model pembelajaran ini bisa membantu guru ketika dirancang dengan tepat karena semakin baik desain pembelajarannya maka proses pembelajaran akan lebih baik. Kelebihan lain model pembelajaran inkuiri terbimbing yaitu meningkatkan keaktifan siswa karena dalam proses pembelajaran siswa dituntut merumuskan masalah, membuat hipotesis, analisis, dan menarik kesimpulan. Siswa belajar dengan cara mencari dan menemukan sendiri jawaban dari suatu masalah sehingga memudahkan siswa memahami konsep. Peningkatan pemahaman konsep siswa berdampak pada peningkatan hasil belajar siswa.

Keberhasilan belajar IPA siswa tergantung dari perlakuan yang diberikan guru pada siswa dalam proses pembelajaran (Widiantono \& Hajono, 2017). Di daerah tertinggal butuh guru dengan motivasi tinggi dalam mengembangkan desain pembelajaran yang berkualitas. Keterampilan guru penting untuk diberdayakan sehingga menunjang kualitas pembelajaran dan meningkatkan hasil belajar IPA siswa. Hasil penelitian ini menginformasikan bahwa desain pembelajaran yang tepat dapat membantu hasil belajar siswa di daerah tertinggal yang memiliki kekurangan pada berbagai aspek seperti fasilitas dan akses informasi.

Berdasarkan berbagai ulasan di atas, apabila guru kreatif dan inovatif dalam memanfaatkan kemampuannya untuk menggunakan model pembelajaran inkuiri terbimbing mulai dari proses mendesain sampai melaksanakannya maka berdampak pada hasil belajar siswa. Guru sebaiknya termotivasi untuk meningkatkan kualitas pendidikan dan tidak menjadikan kondisi daerah tertinggal sebagai alasan untuk tidak berkarya dengan baik.

\section{SIMPULAN DAN SARAN}

Berdasarkan hasil penelitian menunjukkan bahwa $t_{\text {hitung }}=4,940>t_{\text {tabel }}=2,026$ sehingga $\mathrm{H}_{0}$ ditolak dan $\mathrm{H}_{1}$ diterima. Dengan demikian dapat disimpulkan bahwa ada pengaruh yang signifikan penggunaan model pembelajaran inkuiri terbimbing terhadap hasil belajar IPA siswa di SDI Wae Ratun. Keberhasilan dalam belajar tidak terletak pada kondisi daerahnya tetapi terletak pada motivasi, kreativitas, dan inovasi guru dalam mengembangkan perangkat pembelajaran. Keaktifan siswa dalam belajar dapat membantu siswa untuk meningkatkan pemahaman yang selanjutnya berdampak pada peningkatan hasil belajar. Keaktifan siswa didukung dengan kreativitas guru dalam mendesain pembelajaran yang efektif menggunakan berbagai cara yang sesuai dengan situasi dan kondisi kehidupan siswa. 
Hasil Belajar IPA Siswa SD di Daerah Tertinggal dengan Penerapan Model Pembelajaran Inkuiri Terbimbing (Ricardus Jundu, Pius Herman Tuwa, Rosnadiana Seliman)

Penelitian yang memanfaatkan model pembelajaran inkuiri terbimbing dengan materi IPA bagi siswa SD perlu dilakukan kajian lanjutan dengan materi pelajaran IPA lainnya karena penelitian ini hanya terbatas pada materi gaya, gerak, dan energi serta fungsinya. Penelitian selanjutnya juga bisa mengkaji dari variabel terikat lainnya dengan materi pelajaran IPA yang sama karena dalam penelitian ini hanya mengkaji hasil belajarnya saja. Penelitian selanjutnya juga perlu mendalami lebih lanjut hasil penelitian ini dengan membandingkan hasil belajar IPA siswa antara daerah tertinggal dan maju dengan penerapan model pembelajaran yang sama.

\section{DAFTAR PUSTAKA}

Amijaya, L. S., Ramdani, A., \& Merta, I W. 2018. Pengaruh Model Pembelajaran Inkuiri Terbimbing Terhadap Hasil Belajar dan Kemampuan Berpikir Kritis Peserta Didik. J. Pijar MIPA, 13 (2), 94-99.

Damayati. 2014. Penerapan Model Pembelajaran inkuiri Dalam Pembelajaran IPA, JPGSD , 34-35.

Dantes, N. 2012. Metode Penelitian. Yogyakarta : ANDI.

Iswatun, I., Mosik, M., \& Subali, B. 2017. Penerapan Model Pembelajaran Inkuiri Terbimbing untuk Meningkatkan KPS dan Hasil Belajar Siswa SMP Kelas VIII. Jurnal Inovasi Pendidikan IPA, 3(2), 150-160.

Jundu, R., Prodjosantoso, A. K., Ramda, A. H. \& Jelatu, S. 2018. Problem Based Learning (PBL) Menggunakan Pendekatan Saintifik Terhadap Kemampuan Pemecahan Masalah Kimia Siswa, Journal of Komodo Science Education, 1(1), 95-105.

Kuhlthau, C. C. 2007. Guided Inquiry. London: Libraries Unlimited, Inc.

Lestari. 2013. Pengaruh Model Pembelajaran Inkuiri Terbimbing Terhadap Sikap Ilmiah Dan Hasil Belajar IPA, JPGSD, 12-14.

Mertiana. 2011. Pengaruh Implementasi Model Pembeajaran Inkuiri Terbimbing Terhadap Peningkatan Motivasi Belajar Belajar IPA Di Kelas VI SD Santo Yoseph 1denpasar Tahun Ajaran 2011/2012, Jurnal Ilmu Pengetahuan Alam, 109-111.

Pratiwi, K. F., Wijayati, N., Mahatmanti, F. W., \& Marsudi. Pengaruh Model Pembelajaran Inkuiri Terbimbing Berbasis Penilaian Autentik Terhadap Hasil Belajar Siswa. Jurnal Inovasi Pendidikan Kimia, 13(1), 2337-2348.

Roestiyah. 2012. Strategi Belajar Mengajar. Jakarta: Rineka Cipta.

Samatowa, U. 2011. Pembelajaran IPA Di Sekolah Dasar. Jakarta Barat: Permata Puri Media.

Santiasih. 2013. Pengaruh Model Pembelajaran Inkuiri Terbimbing Terhadap Sikap Ilmiah Dan Hasil Belajar IPA Siswa Kelas V SD No.1 Kerombakan Kecamatan Kuta Utara Kabupaten Bandung Tahun Pelajaran 2013/2014, JPGSD, 203-205.

Slameto. 2010. Belajar Dan Faktor-Faktor Yang Mempengaruhi. Jakarta: PT Rineka Cipta.

Sumarni, S., Santoso, B. B., \& Suparman, A. R. Pengaruh Pembelajaran Inkuiri Terbimbing Terhadap Hasil Belajar Kognitif Peserta Didik di SMA Negeri 01 Manokwari. Jurnal Nalar Pendidikan, 5(1), 21-30.

Syarifuddin, A. 2011. Penerapan Metode Inkuiri Terbimbing Untuk Meningkatkan Pemahaman Konsep Dan Keterampilan Berpikir Kritis Siswa Kelas VII Materi Tentang Cahaya, Jurnal Pendidikan Sains Indonesia , 45-48.

Udiani, K., Marhaeni, A. A. I. N., \& Arnyana, I. B. P. 2017. Pengaruh Model Pembelajaran Inkuiri Terbimbing Terhadap Hasil Belajar IPA dengan Mengendalikan Keterampilan Proses Sains Siswa Kelas IV SD No 07 Benoa Kecamatan Kuta Selatan Kabupaten Badung. e-Journal Program Pascasarjana Universitas Pendidikan Ganesha, 7(1). 
Wahyuni. 2016. Pengaruh Model Pembelajaran Inkuiri Terbimbing Dengan Metode Eksperiemen Terhadap Hasil Belajar Fisika Siswa Kelas XII IPA SMAN 2 Martaram Tahun Pelajaran 2016/2017, Jurnal Pendidikan Fisikan Dan Teknologi , 56-57.

Widiantono, N \& Hajono, N. 2017. Penerapan Model Pembelajaran Interaktif untuk Meningkatkan Aktivitas dan Hasil Belajar IPA Siswa Kelas 5 SD, Scholaria: Jurnal Pendidikan dan Kebudayaan, 7(3), 199 - 213.

Wulandari, D. 2012. Pengaruh Penggunaan Metode Inkuiri Terhadap Hasil Belajar IPA Materi Cahaya Dan Sifat-Sifat Pada Siswa Kelas V SDN Mranggen Tengah Kecamatan Bansari Tahun Ajaran2011/2012, Jurnal Pendidikan Ilmu Pengetahuan Alam, 67-68.

Wulanningsih. 2012. Pengaruh Model Pembelajaran Inkuiri Terhadap Keterampilan Proses Sains Ditinjau Dari Kemampuan Akademik Siswa SMA Negri 5 Surakarta, Jurnal Pendidikan Biologi, 4(2), 33-34.

Zani, R., Adlim, \& Safitri, R. 2018. Penerapan Model Pembelajaran Inkuiri Terbimbing Pada Materi Fluida Statis Untuk Meningkatkan Hasil Belajar dan Keterampilan Proses Sains Siswa. Jurnal IPA dan Pembelajaran IPA, 2(2), 56-63. 